Dhaka Univ. J. Biol. Sci. 30(1): 23-34, 2021 (January)

\title{
COMPARATIVE STUDY OF PROTOZOAN PARASITE COMMUNITIES BETWEEN ANABAS TESTUDINEUS AND CHANNA PUNCTATUS
}

\author{
Md Aminul Islam Bhuiyan*, Fatima Nahar Kabita, Zannatun Nahar Jhinu \\ AND MD HAMIM BHUIYAN ${ }^{1}$ \\ Department of Zoology, University of Dhaka, Dhaka-1000, Bangladesh
}

Key words: Protozoa, Parasite, Infection, Diversity, Anabas testudineus, Channa punctatus

\begin{abstract}
The study was conducted to determine the comparative occurrence of protozoan parasites of two host species- Anabas testudineus and Channa punctatus. The host fishes were collected from April, 2018 to March, 2019 from freshwater bodies of Mymensingh, Kishoreganj, Faridpur and Jashore districts of Bangladesh. Three species of myxozoa (Henneguya mystusia, Henneguya qadrii and Henneguya acerinae) and four genera/species of ciliophora (Trichodina acuta, Trichodina sp., Epistylis lwoffi and Amphileptus disciformis) in A. testudineus; three genera/species of myxozoa (Henneguya chaudhuryi, Henneguya bengalensis and Myxobolus sp.), three species of ciliophora (Trichodina pediculus, Epistylis lwoffi and Apisoma piscicolum) and a few actinosporean stage of myxoza in C. punctatus were identified. The prevalence of protozoan infections were found higher in $A$. testudineus (76.19\%) compare to C. punctatus (51.72\%). However, mean intensity was relatively higher in C. punctatus $(95.93 \pm 41.53)$ than that of A. testudineus $(71.38 \pm 32.26)$. Myxozoans were clearly dominant group in both hosts. Multiple parasitic infections were higher in A. testudineus. The highest parasitic infection was observed in Mymensingh (100\%) and lowest in Jashore (40\%) in A. testudineus, whereas it was highest in fish of Faridpur (100\%) and lowest in Mymensingh (33.33\%) in C. punctatus. Shannon Diversity Indices indicated that the parasite community was poorly diverged in both hosts of all study areas. However, Simpson's Diversity revealed that, parasites community was moderately diverged in both hosts in Mymensingh and in other study areas they were poorly diverged.
\end{abstract}

\section{Introduction}

Fish is one of the principal sources of protein for human being and other animals in the tropics. Being one of the cheapest sources of animal protein, fish plays a major role in the diet of Bangladeshis. There are 265 freshwater fish species belonging to 55 families $^{(1)}$ available at freshwater bodies in Bangladesh. Among the fish species in Bangladesh Anabas testudineus and Channa punctatus are major contributors to the fisheries sector as

*Author for correspondence: aminul_zool@du.ac.bd>. ${ }^{1}$ Emerging Infectious Disease Laboratory, Icddr,b, Mohakhali, Dhaka-1212, Bangladesh.

DOI: https://doi.org/10.3329/dujbs.v30i1.51806 
they are very common as well as fairly popular. They possess a great economical, nutritional and medicinal role in our country along with providing employment for rural people living in the coastal regions. Therefore, it is important to develop a good management practice for disease free fish production.

A. testudineus is a small freshwater indigenous air-breathing fish popularly known as climbing perch which can live without water for days and so were found alive on most of tree tops and hence its name. They remain buried under the mud during dry season. This fish is a column feeder, feed on macrophytic vegetation, shrimps and fish fry and also a larvicidal fish, feeds upon mosquito larvae and hence used to control mosquito larvae ${ }^{(2)}$.

The snake headed fish C. punctatus is the most important species of inland fisheries of Bangladesh. It is mud-loving fish and due to its food habit, it can act as an intermediate host for many helminth parasites ${ }^{(3)}$. As the C. punctatus is most popular fish in the country, their abundance is reducing due to over exploitation, environmental stress and the occurrence of various diseases. As a consequence, parasitic infestation may initiate declination in fisheries stock over the time.

In general, fishes are suitable carrier of parasites because they act as an intermediate host of various parasites for the completion of developmental stages of their life cycle. Parasites cause massive destruction of skin, epithelium and gill; thereby affect fish population by growth retardation, weight loss and suppression of reproductive activity even mortality ${ }^{(4)}$. Apart from mortality treatment expenses, growth reduction during and after outbreak of disease cause economic loss and this militates against expansion of aquaculture(5). However, the report on the fish parasites, their frequency and distribution in fish is very inadequate in Bangladesh. Various metazoan parasites like monogeneans, digeneans, larval cestodes and ectoparasitic crustaceans have been reported in these host fish of Bangladesh ${ }^{(6-10)}$ but report on protozoan parasites are limited and not homogeneous. Moreover, they were not been studied thoroughly in Bangladesh and only a little knowledge about the distribution, occurrence of ecto-protozoan parasite of $A$. testudineus and C. punctatus is available ${ }^{(11-14)}$. Therefore, it is essential to know the current status of protozoan infestation in the wild freshwater fish. In the present study, the relative occurrence of two fish species named A. testudineus and C. punctatus are studied as being two more popular edible species. The present study was an attempt to build a base line data of protozoan parasites of the two fish species and to control most of the diseases of them in natural population in Bangladesh. Since both host lives in similar habitats comparison of parasite community will reveal the causes behind differences.

\section{Materials and Methods}

Collection of host samples: A total of 50 specimens of host fish were collected randomly from four areas of which, 21 fishes were Anabas testudineus and 29 fishes were Channa 
punctatus. Sample size of four areas was not equal. Host fish were collected alive from the freshwater bodies of Kishoreganj (Kuliar char- 2410'40" N, 90 50'57" E), Mymensingh

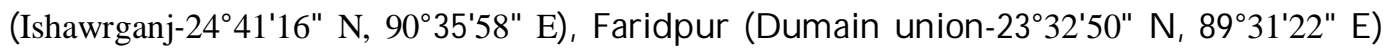
and Jashore (Purondorpur, Jhikorgacha upazila- 235'51" N, 89 ${ }^{\circ} 5^{\prime} 53^{\prime \prime}$ E) with the help of fishermen from mid of the April 2018 to end of the March 2019.

Sample preparation: The outer surface of fish was examined immediately after capture using a magnifying glass. External surface of the fish was examined and recorded for any abnormalities. Specimens were kept moist during examination by spraying them with a fine mist of water. After collecting the samples, their total length and total weights were measured. Body slime, gill slime and blood of host fish were collected which are the best sources for protozoan parasite. Smears of body slime, gill slime and blood were made on glass slides on the spot of collection and fixed them in ethanol for further microscopic observation in the laboratory.

Giemsa's stain technique was used for rapid demonstration of nuclei in ciliates and spores in microsporidian. Klein's dry silver impregnation method was used for staining mobile peritrichs and other ciliates. The slides were observed under microscope to detect the presence or absence of protozoan parasites. Parasites of selected organ were counted and recorded. The prepared slides were observed under the compound microscope and visualized by $4 \mathrm{x}, 10 \mathrm{x}$, and 40x lenses for comprehensive morphological details of the protozoan parasites. The number of observed parasites was counted for statistical analysis and microscopic photographs were captured for identification of species with the help of 10-megapixel digital camera.

Protozoans were identified according to the description of Lom and Dyková(15), Kalavati and Nandi(16), Bashě and Abdullah(17) and Kibria et al.(18). Some parasites (Myxobolus sp. and Trichodina sp.) could not be identified up to species level due to the unavailable sources of articles. So, it seems reasonable to make their detail observation to come to a conclusion.

Calculation: Measurement of prevalence, mean intensity and abundance of infection were calculated according to Margoles et al. (19). Simpson's Diversity Index ${ }^{(20)}$ was used to evaluate both species richness and abundance of parasites found in the samples. Shannon's Diversity index ${ }^{(21)}$ was used to measure the diversity. The most commonly used index of evenness based on the Shannon- Wiener index (22) was used. Margalef Index of Species Richness ${ }^{(23)}$ was used to evaluate the richness of parasites within the samples.

Data analysis: Statistical analyses were carried out using Microsoft Excel 2010 and IBM SPSS version 20. Fisher's Exact test (as the sample size was small fisher exact test was done instead of Chi square test) was performed. Significance levels were set at $\mathrm{p} \leq 0.05$. 


\section{Results and Discussion}

Comparative study of different aspects of protozoan infestation between Anabas testudineus and Channa punctatus revealed some differences in almost all aspects of infestation. The protozoan parasites were collected from body slime and gills but no parasites were found in blood samples. Out of 16 infected host (A. testudineus) a total of 1142 protozoan parasites were collected from different areas of body ( 21 fish examined) and a total of 1437 protozoan individuals were collected from different body parts of 15 infected C. punctatus (out of 29 fish examined) in the present study. The overall prevalence of A. testudineus was higher $(76.19 \%)$ than C. punctatus $(51.72 \%)$ whereas mean intensity was higher $(95.93 \pm 41.53)$ in $C$. punctatus than A. testudineus $(71.38 \pm 32.26)$. It was settled that, $A$. testudineus was more infected by protozoan fauna than $C$. punctatus. Altogether 13 genera/species and Actinosporean stage of protozoan parasites have been identified from the two host fish (Table 1).

Table 1. Occurrence of protozoan parasites recorded from Anabas testudineus and Channa punctatus.

\begin{tabular}{|c|c|c|c|c|c|c|}
\hline \multirow{2}{*}{$\begin{array}{l}\text { Group of } \\
\text { the } \\
\text { parasites }\end{array}$} & \multicolumn{3}{|c|}{ Anabas testudineus } & \multicolumn{3}{|c|}{ Channa punctatus } \\
\hline & Parasites & Sampling area & $\begin{array}{l}\text { Site of } \\
\text { infection }\end{array}$ & Parasites & Sampling area & $\begin{array}{l}\text { Site of } \\
\text { infection }\end{array}$ \\
\hline \multirow[t]{4}{*}{ Myxozoa } & $\begin{array}{l}\text { Henneguya } \\
\text { acerinae }\end{array}$ & $\begin{array}{l}\text { Mymensingh, } \\
\text { Kishoreganj }\end{array}$ & Gill & $\begin{array}{l}\text { Henneguya } \\
\text { chaudhuryi }\end{array}$ & Jashore & Gill \\
\hline & $\begin{array}{l}\text { Henneguya } \\
\text { qadrii }\end{array}$ & Mymensingh & Gill & $\begin{array}{l}\text { Henneguya } \\
\text { bengalensis }\end{array}$ & $\begin{array}{l}\text { Faridpur, } \\
\text { Jashore }\end{array}$ & Gill \\
\hline & \multirow[t]{2}{*}{$\begin{array}{l}\text { Henneguya } \\
\text { mystusia }\end{array}$} & $\begin{array}{l}\text { Mymensingh, } \\
\text { Kishoreganj, }\end{array}$ & $\begin{array}{l}\text { Gill, } \\
\text { Body }\end{array}$ & $\begin{array}{l}\text { Myxobolus } \\
\text { sp. }\end{array}$ & Kishoreganj & Gill \\
\hline & & $\begin{array}{l}\text { Faridpur, } \\
\text { Jashore }\end{array}$ & slime & $\begin{array}{l}\text { Actinosporean } \\
\text { stage }\end{array}$ & Mymensingh & Body slime \\
\hline \multirow[t]{4}{*}{ Ciliophora } & $\begin{array}{l}\text { Trichodina } \\
\text { acuta }\end{array}$ & $\begin{array}{l}\text { Kishoreganj, } \\
\text { Faridpur }\end{array}$ & $\begin{array}{l}\text { Gill, } \\
\text { Body } \\
\text { slime }\end{array}$ & $\begin{array}{l}\text { Trichodina } \\
\text { pediculus }\end{array}$ & $\begin{array}{l}\text { Mymensingh, } \\
\text { Faridpur, } \\
\text { Jashore }\end{array}$ & $\begin{array}{l}\text { Body slime, } \\
\text { Gill }\end{array}$ \\
\hline & $\begin{array}{l}\text { Trichodina } \\
\text { sp. }\end{array}$ & $\begin{array}{l}\text { Kishoreganj, } \\
\text { Jashore }\end{array}$ & Gill & Epistylis lwoffi & $\begin{array}{l}\text { Faridpur, } \\
\text { Jashore }\end{array}$ & Body slime \\
\hline & $\begin{array}{l}\text { Epistylis } \\
\text { lwoffi }\end{array}$ & $\begin{array}{l}\text { Faridpur, } \\
\text { Jashore }\end{array}$ & $\begin{array}{l}\text { Body } \\
\text { slime }\end{array}$ & $\begin{array}{l}\text { Apiosoma } \\
\text { piscicolum }\end{array}$ & Jashore & Body slime \\
\hline & $\begin{array}{l}\text { Amphileptus } \\
\text { disciformis }\end{array}$ & Faridpur & $\begin{array}{l}\text { Body } \\
\text { slime }\end{array}$ & & & \\
\hline
\end{tabular}

In the present study, Trichodina acuta infection in host $A$. testudineus is the first record as a new host in Bangladesh. Although it was previously recorded in Bangladesh in another freshwater species, Mystus bleekeri(18). In A. testudineus, myxozoan parasite Henneguya qadrii and Henneguya mystusia has been first recorded in Bangladesh. 
Moreover, till to date, except Trichodina anabasi ${ }^{(12,13)}$ and Tripartiella sp. no protozoan parasitic infestations were recorded in A. testudineus in Bangladesh. Although Henneguya qadrii(25) infecting C. punctatus and Henneguya mystusia(26) infecting Mystus sp. were previously recorded in India. The rest three parasites were first recorded in these hosts and also as first locality recorded in Bangladesh. On the other hand, Trichodina pediculus was previously recorded in C. punctatus in Bangladesh ${ }^{(18,19)}$. Henneguya chaudhuryi(27,28) and Henneguya bengalensi ${ }^{(29)}$ collected from $C$. punctatus were previously recorded in this host in India but is newly in Bangladesh. The rest two parasites were the first record infecting these fishes in Bangladesh. Trichodina cyprinocola, Trichodina pediculus, Trichodina sp., Chilodonella sp., Ichthyobodo sp., Actinophrys sp., Ichthyophthirius multifilis, and Myxobolus sp. were recorded from C. punctatus in Bangladesh ${ }^{(14,24)}$.

Table 2. Updated list of protozoan parasites from Anabas testudineus and Channa punctatus in this region (Bangladesh, India and Pakistan).

\begin{tabular}{|c|c|c|c|}
\hline \multicolumn{2}{|c|}{ Anabas testudineus } & \multicolumn{2}{|c|}{ Channa punctatus } \\
\hline Parasites & References & Parasites & References \\
\hline Henneguya acerinae $\Delta \Omega$ & Present study & $\begin{array}{l}\text { Henneguya } \\
\text { chaudhuryi } \Delta\end{array}$ & $\begin{array}{l}\text { Bajpai and Halder, 1982, } \\
\text { Chaudhary et al. } 2017 \\
\text { And Present study }\end{array}$ \\
\hline Henneguya mystusia $\mathbf{\Omega}$ & $\begin{array}{l}\text { Kumar } 2000 \text { and } \\
\text { Present study }\end{array}$ & $\begin{array}{l}\text { Henneguya } \\
\text { bengalensis } \Delta\end{array}$ & $\begin{array}{l}\text { Raychaudhuri and } \\
\text { Chakravarty } 1970 \text { and } \\
\text { Present study }\end{array}$ \\
\hline Henneguya qadrii $\Delta$ & $\begin{array}{l}\text { Lalitha } 1965 \text { and } \\
\text { Present study }\end{array}$ & Myxobolus sp. & * \\
\hline Trichodina acuta $\S \Omega$ & $\begin{array}{l}\text { Kibria et al. } 2010 \\
\text { and Present study }\end{array}$ & $\begin{array}{l}\text { Actinosporean } \\
\text { stage } \Delta \Omega\end{array}$ & Present study \\
\hline Trichodina sp. & * & $\begin{array}{l}\text { Trichodina } \\
\text { pediculus } \S\end{array}$ & $\begin{array}{l}\text { Deb et al. } 2015 \text { and } \\
\text { Present study }\end{array}$ \\
\hline Epistylis lwoffi $\Delta \mathbf{\Omega}$ & Present study & Epistylis lwoffi $\Delta \Omega$ & Present study \\
\hline $\begin{array}{l}\text { Amphileptus } \\
\text { disciformis } \Delta \mathbf{\Omega}\end{array}$ & Present study & $\begin{array}{l}\text { Apisoma } \\
\text { piscicolum } \Delta \mathbf{\Omega}\end{array}$ & Present study \\
\hline
\end{tabular}

*References of parasites identified up to genus level have not been included in this chart. $\Omega$ New host record; $\Delta$ New locality record in Bangladesh; § Previously recorded in Bangladesh.

Two groups (myxozoa and chiliophora) of protozoan parasites were recorded from both A. testudineus and C. punctatus in the present study. In comparison with Chiliophora, Myxozoa was clearly dominant group in both hosts (Fig. 1). Previous record was not found on all the groups of protozoan parasites in both host fishes. Therefore, direct comparison is not possible. 
In A. testudineus, multiple species of parasitic infection was found higher than single species of parasitic infection at a time (Fig. 2). On the other hand, in C. punctatus, single species of parasitic infection was found higher than multiple species infection at a time (Fig. 2). Moreover, $23.81 \%$ and $48.28 \%$ hosts were not infected by parasites in $A$. testudineus in C. punctatus at a time (Fig. 2). Previous record was not available on multiple infections of protozoan parasites in these host fishes. However, Kaur and Katoch ${ }^{(30)}$ reported that $65.15 \%$ of native carp fish had mixed infection of myxozoan species at a time and that result was slightly similar to present study. Multiple infections might be happened due to sharing the same habitat by two hosts.

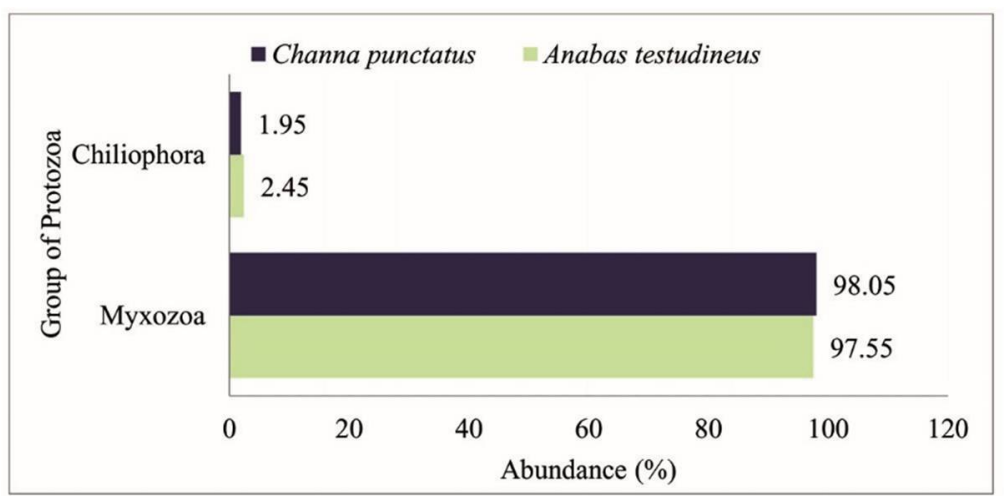

Fig. 1. Comparison of parasitic infestation by Myxozoa and Chiliophora between $A$. testudineus and C. punctatus

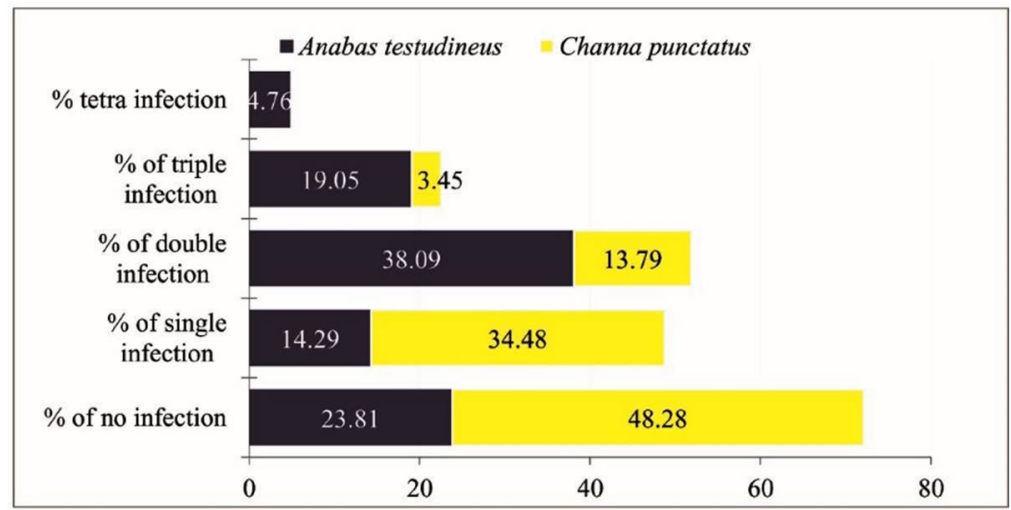

Fig. 2. Multiple infestations of different protozoan parasites in A. testudineus comparing with

C. punctatus.

A total of 7 genera/species of protozoan parasites were found in A. testudineus and 6 genera/species and actinosporean stages of protozoan parasites were found in $C$. punctatus. The chiliophora, Epistylis lwoffi was common in both A. testudineus and C. punctatus (Table 3). 
Rest of the species of protozoan parasites in both host fishes were host specific. But while considering generic level, Henneguya and Trichodina were common in both hosts (Table 3). In the present study, the prevalence of Henneguya mystusia was closely similar to the findings of Kumar(26) who reported that $65 \%$ of Henneguya mystusia were found in Aplocheilus lineatus in India. Kibria et al.(18) reported $46.3 \%$ prevalence of Trichodina acuta in host fish, Mystus bleekeri in Bangladesh. Asmat et al.(12) and Kibria et al.(13) reported $19.6 \%$ and $40.0 \%$ prevalence respectively for Trichodina anabasi in A. testudineus in Bangladesh. To the best of our knowledge, no previous record of Henneguya acerinae, Henneguya qadrii, Amphileptus disciformis and Epistylis lwoffi has been found in these hosts as well as in the mentioned locality in Bangladesh.

Table 3. Overall prevalence and mean intensity of different species of protozoan parasites in A. testudineus and C. punctatus.

\begin{tabular}{|c|c|c|c|c|c|}
\hline \multicolumn{3}{|c|}{ Anabas testudineus } & \multicolumn{3}{|c|}{ Channa punctatus } \\
\hline Name of parasites & $\begin{array}{c}\text { Prevalence } \\
(\%)\end{array}$ & $\begin{array}{l}\text { Mean Intensity } \\
\quad( \pm \mathrm{SD})\end{array}$ & Name of parasites & $\begin{array}{c}\text { Prevalence } \\
(\%)\end{array}$ & $\begin{array}{l}\text { Mean Intensity } \\
\quad( \pm \mathrm{SD})\end{array}$ \\
\hline \multicolumn{6}{|l|}{ Myxozoa } \\
\hline Henneguya acerinae & 28.57 & $76.83 \pm 53.55$ & Henneguya chaudhuryi & 6.90 & $240.0 \pm 62.81$ \\
\hline Henneguya qadrii & 23.81 & $86.40 \pm 60.28$ & Henneguya bengalensis & 13.79 & $197.75 \pm 85.33$ \\
\hline \multirow[t]{2}{*}{ Henneguya mystusia } & 52.38 & $19.55 \pm 21.51$ & Myxobolus sp. & 6.90 & $67.5 \pm 22.36$ \\
\hline & & & Actinosporea stage & 6.90 & $1.5 \pm 0.41$ \\
\hline \multicolumn{6}{|l|}{ Chiliophora } \\
\hline Trichodina acuta & 23.81 & $2.40 \pm 1.29$ & Trichodina pediculus & 24.14 & $2.00 \pm 1.02$ \\
\hline Trichodina sp. & 14.29 & $1.33 \pm 0.51$ & Epistylis lwoffi & 10.34 & $3.30 \pm 1.11$ \\
\hline Epistylis lwoffi & 9.52 & $2.0 \pm 0.68$ & Apisoma piscicolum & 3.45 & $4.0 \pm 0.74$ \\
\hline Amphileptus disciformis & 14.29 & $2.67 \pm 1.02$ & & & \\
\hline
\end{tabular}

Chaudhary et al.(28) reported higher percentage (59.3\%) of C. punctatus infection by Henneguya chaudhuryi in India which was relatively higher than that of found in this study. Deshpande and Verma ${ }^{(31)}$ reported that $28.1 \%$ of Channa striatus were found to be infected with Myxobolus sp. in India which was higher than found in the present study. Deb et al.(24) reported that $3.33 \%$ of C. punctatus were infected with Trichodina pediculus and $33.33 \%$ of C. punctatus were infected with Trichodina cyprinocola in their study. Some $32.50 \%$ of Trichodina sp. ${ }^{(14)}$ was found in C. punctatus in Bangladesh. Trichodinids were neither host nor site specificic ${ }^{(32)}$. Prevalence was found $8.33 \%$ of Apiosoma sp. ${ }^{(33)}$ that was previously recorded in Bangladesh from skin of Cirrhinus reba but no infection status has been found in C. punctatus previously. Apisoma piscicolum showed a diverse range of host variability and has a cosmopolitan distribution in Europe, Asia and South Africa ${ }^{(34)}$. 
Mixed infections of Epistylis lwoffi and Apiosoma piscicola were found in the fry of Salvelinus fontinalisin in Canada( ${ }^{(3)}$. Similar findings had been also recorded in the present study.

Table 4. Richness, evenness and diversity of the parasite communities of A. testudineus and $C$. punctatus.

\begin{tabular}{lcc}
\hline Characteristics & Anabas testudineus & Channa punctatus \\
\hline Number of fish examined & 21 & 29 \\
\% of fish infected & 76.19 & 58.62 \\
No. of parasites collected & 1142 & 1437 \\
No. of parasite species & 7 & 7 \\
Species evenness & 0.641 & 0.526 \\
Species of Richness ' $\mathrm{R}^{\prime}$ & 0.852 & 0.825 \\
Shannon Diversity Index (H) & 1.249 & 1.026 \\
Simpson's Diversity Index (D) & 0.655 & 0.577 \\
\hline
\end{tabular}

A. testudineus had comparatively higher value (0.852) of parasite richness than $C$. punctatus (0.825. Evenness of parasite distribution showed moderate value in both $A$. testudineus (0.641) and C. punctatus (0.526) which indicated that protozoan parasite community was distributed moderately in their host and not well diverged (Table 4).

Shannon Diversity Index ( $\mathrm{H}=1.249$ and 1.026) of protozoan fauna in A. testudineus and $C$. punctatus, respectively showed that parasite community was poorly diverged and host fishes were not infested by more protozoan parasite. But Simpson's Diversity Index ( $D=$ 0.655 and 0.577 ) of protozoan fauna in A. testudineus and C. punctatus respectively indicated that parasite community was moderately diverged in both hosts (Table 4).

Host fishes, A. testudineus and C. punctatus were collected from four selected study areas and found to be infected by various protozoan parasites. In case of A. testudineus, samples of Mymensingh district was found to be severely infected among all the districts; whereas in C. punctatus, fishes of Faridpur district were found to be more infected than all other districts (Table 5). It was concluded that, A. testudineus and C. punctatus of Faridpur area were found to be more infected than rest of the study sites during the study period. The association of parasitic infestation with study areas was not statistically significant in case of both A. testudineus $(\mathrm{p}=0.141$, since $\mathrm{p} \leq 0.05)$ and $C$. puntatus $(\mathrm{p}=0.118$, since $\mathrm{p} \leq 0.05)$ species. The myxozoan parasite, Henneguya mystusia was found in all the study sites in A. testudineus. On the other hand, the chiliophoran parasite, Epistylis lwoffi was only found in Faridpur and Jashore samples in both hosts. 
During the present study, protozoan parasites exhibited variation in species composition, prevalence and mean intensity in both host, which might be dependent upon the factors such as parasite biology, host size, feeding habits and habitat of the host, water quality, metabolic state and weak immune system of the host fish. Banerjee and Bandyopadhyay ${ }^{(36)}$ reported that, water quality has a great impact on the abundance of fish pathogens and their ability to survive on host.

Table 5. Infestation by protozoan parasites in different study areas in Anabas testudineus and Channa punctatus.

\begin{tabular}{lcccc}
\hline & \multicolumn{2}{c}{ Anabas testudineus } & \multicolumn{2}{c}{ Channa punctatus } \\
\cline { 2 - 5 } Study area & $\begin{array}{c}\text { Prevalence } \\
(\%)\end{array}$ & $\begin{array}{c}\text { Mean intensity } \\
( \pm S D)\end{array}$ & $\begin{array}{c}\text { Prevalence } \\
(\%)\end{array}$ & $\begin{array}{c}\text { Mean intensity } \\
( \pm S D)\end{array}$ \\
\hline Mymensingh & 100 & $151.67 \pm 56.22$ & 33.33 & $2.67 \pm 0.58$ \\
Kishoregonj & 80 & $24.00 \pm 14.01$ & 40 & $67.5 \pm 20.37$ \\
Faridpur & 80 & $26.50 \pm 10.31$ & 100 & $85.00 \pm 47.26$ \\
Jashore & 40 & $15.00 \pm 4.24$ & 50 & $173.8 \pm 60.44$ \\
\hline
\end{tabular}

After analyzing the richness, evenness and diversity of parasite communities of different sampling sites of both hosts, the site wise comparison of richness value between two hosts showed that, samples collected from Kishoreganj district had the highest (0.657) parasite richness value in A. testudineus whereas samples collected from Jashore had the highest (0.550) species richness in C. punctatus (Table 6).

Table 6. Richness and evenness of the parasite communities of different sampling areas between Anabas testudineus and Channa punctatus.

\begin{tabular}{lcccc}
\hline \multirow{2}{*}{ Study area } & \multicolumn{2}{c}{ Richness } & \multicolumn{2}{c}{ Evenness } \\
\cline { 2 - 5 } & A. testudineus & C. punctatus & A. testudineus & C. punctatus \\
\hline Mymensingh & 0.294 & 0.138 & 0.955 & 0.703 \\
Kishoregonj & 0.657 & 0.00 & 0.385 & 0.00 \\
Faridpur & 0.643 & 0.275 & 0.152 & 0.402 \\
Jashore & 0.588 & 0.550 & 0.465 & 0.512 \\
\hline
\end{tabular}

Evenness of parasite distribution in samples of both hosts were collected from Mymensingh district and showed moderately higher value, which meant that parasite communitiy structure was well constructed and well diverged (Table 6).

Shannon Diversity Index $(\mathrm{H})$ indicated that samples of both hosts and study sites were not infested by more parasites and the parasite communities were poorly diverged (Table 7). In contrast Simpson's Diversity Index (D), indicated that fish samples of $A$. 
testudineus collected from Mymensingh were infected by parasites community which was moderately diverged and rest of the sites were not infected by more parasites and the parasite communities were poorly diverged (Table 7). In case of C. punctatus, parasite communities were moderately diverged in Mymensingh and Jashore (Table 7). Whereas, fish samples collected from Kishoreganj had no parasites diversity and fish samples collected from Faridpur was not infected by more parasites and the parasite community was poorly diverged (Table 7). Direct comparison was not drawn due to lack of available previous findings.

Table 7. Shannon Diversity Index (H) and Simpson's diversity Index (D) of the parasite communities of the different sampling areas in Anabas testudineus and Channa punctatus.

\begin{tabular}{lcccc}
\hline \multirow{2}{*}{ Study area } & \multicolumn{2}{c}{ Shannon Diversity Index $(\mathrm{H})$} & \multicolumn{2}{c}{ Simpson's diversity Index (D) } \\
\cline { 2 - 5 } & A. testudineus & C. punctatus & A. testudineus & C. punctatus \\
\hline Mymensingh & 0.773 & 0.662 & 0.518 & 0.536 \\
Kishoregonj & 0.533 & 0.00 & 0.248 & 0.00 \\
Faridpur & 0.557 & 0.167 & 0.272 & 0.064 \\
Jashore & 0.563 & 0.748 & 0.301 & 0.504 \\
\hline
\end{tabular}

Since the host fishes play an important role as popular edible fish in Bangladesh, assessing the parasitic infestation is necessary to limit their further damage. A primary database of comparative analysis between protozoan parasites of C. punctatus and A. testudineus has been established by the present work which will be helpful for further study with a broader extent including more study areas and larger sample size.

\section{Acknowledgements}

The present work was financially supported by 'Ministry of Education' through ‘Bangladesh Bureau of Educational Information and Statistics' (BANBEIS) and 'Ministry of Science and Technology'.

\section{Reference}

1. Rahman AKA 2005. Freshwater Fishes of Bangladesh. The Zoological Society of Bangladesh, Dhaka. pp. 284-286.

2. Akhter M, J D'silva and A Khatun 1997. Helminth parasites of Anabas testudineus Bloch in Bangladesh. Bangladesh J. Zool. 25(92): 135-138.

3. Ghani MO and AI Bhuiyan 2011. Community structures of endoparasitic helminths of Channa punctatus from a fresh water river and a polluted lagoon of Bangladesh. Bangladesh J. Zool. 39(2): 173-185. 
4. Luangphai P, C Wongsawad, K Khumchoo and P Sripalwit 2004. Survey of helminths in climbing perch (Anabas testudineus) from San Sai district, Chiang Mai Province. Southeast Asian J Trop Med Public Health 35: 288-90.

5. Enayat SAR 2011. A review of some ecto-and endo protozoan parasites infecting Sarotherodon Galilaeus and Tilapia Zillii from Damietta Branch of River Nile, Egypt. Journal of American Science 7(3): 362-373.

6. Bashirullah AKM 1973. A brief survey of the helminth fauna of certain marine and freshwater fishes of Bangladesh. Bangladesh J. Zool. 1(1): 63-81.

7. Alam MJ, M Rakibuzzaman and MM Hasan 2010. Comparative study of endo-parasitic infestation in Channa punctatus (Bloch, 1793) collected from Hatchery and Sewage lagoon. Nature and Science 8(5): 152-156.

8. Chandra KJ, M Hasan and SS Basak 2011.Prevalence of Genarchopsis dasus (Digenea: Hemiuridae) in Channa punctatus of Mymensingh. Bangladesh Vet. 28:47-54.

9. Ghani MO, AI Bhuiyan and J Bushra 2014. Community structure analysis of endoparasitic helminths of Anabas testudineus from unpolluted and polluted sites of a freshwater body of Dhaka. The Dhaka Univ. J. Biol. Sci. 23(1): 27-38.

10. Bhuiyan AI, J Bushra and O Ghani 2014. Abundance and distribution of endoparasitic helminths in Anabas testudineus (Bloch, 1792) from a polluted beel of Bangladesh. Bangladesh J. Zool. 42(1): 1-10.

11. Sanaullah M 1996. On the occurrence of Trypanosoma sp. (Protozoa: Kinetoplastida) in Channa punctatus (Bloch) and Anabas testudineus (Bloch) at Beel Mahmoodpur, Faridpur. Bangladesh J. Zool. 24(2): 195-198.

12. Asmat GSM, N Mohammad and N Sultana 2003. Trichodina anabasi sp. n. (Ciliophora: Trichodinidae) from climbing perch, Anabas testudineus (Bloch, 1795) (Anabantidae) in Chittagong. Pakistan J. Biol. Sci. 6: 1608-1611.

13. Kibria MM, I Hadiul, MMA Habib, LC Shutradhar and GSM Asmat 2011. Trichodinid ectoparasites (Ciliophora: Trichodinidae) from the gills of freshwater fishes in the Shitalakhsya River, Bangladesh. In Advances in Parasitology: A Novel Approach Towards a Disease Free World. Proceedings of the 22nd National Congress on Parasitology, University of Kalyani, West Bengal, India, October 30-November 1, 2010. pp. 135-149.

14. Miah MF, M Deb, H Ali, MMA Quddus and K Ahmed 2013. Comparative surveillance of parasitic infestation in Channa punctatus (Osteichthys: Channidae) collected from open and closed water in Sylhet, Bangladesh. Adv. Zool. Bot. 1(1): 17-23.

15. Lom J and I Dyková 1992. Protozoan parasites of fishes: Developments in aquaculture and fisheries science. Elsevier, Amsterdam, Vol. 26. pp. 315.

16. Kalavati C and NC Nandi 2007. Handbook on myxosporean parasites of Indian fishes. Zoological Survey of India, pp. 305.

17. Bashě SKR. and SMA Abdullah 2010. Parasitic fauna of spiny eel Mastacembelus mastacembelus from Greater Zab river in Iraq. Iranian J. Veter. Res. 11(1): 18-27.

18. Kibria MM, H Islam, MMA Habib and GSM Asmat 2010. Trichodina shitalakshyae sp. n. and Trichodina acuta Lom, 1961 (Ciliophora: Trichodinidae) from the freshwater fishes in the Shitalakhya River, Bangladesh. Wiadomooecei Parazytologiczne, Poland 56(2): 153-161. 
19. Margolis L, GW Esch, JC Holmes, AM Kuris and GA Schad 1982. The use of ecological terms in parasitology (report of an ad hoc committee of the American Society of Parasitologists). J. Parasitol. 68: 131-133.

20. Simpson EH 1949. Measurement of diversity. Nature 163: 688.

21. Shannon CE and W Weaver 1949. The mathematical theory of communication. University Illinois Press, Urbana, Il.

22. Pielou EC 1977. Mathematical Ecology. Wiley, New York.

23. Margalef R 1958. Information theory in biology. General Systems Yearbook. 3: 36-71.

24. Deb M, FM Miah, M Rahman and KZ Khan. 2015. Trichodinid Parasites on the Gills of Channa punctatus from the Wild and Cultured Environments in Sylhet, Bangladesh. Hindawi Publishing Corporation Vol. 2015. pp. 4. Article ID 161562.

25. Lalitha PK 1965. On a new species of Henneguya (Protozoa: Myxosporidia) from an Indian fresh water fish, Ophicephalus gachua. Riv. Parasitol. 26: 79-84.

26. Krishna Kumar K 2000. Studies on Myxosporean parasites of fishes of Kerala. Ph.D Thesis, University of Kerala, India.

27. Bajpai RN and DP Haldar 1982. A new myxosporidian, Unicauda chaudhuryi n. sp., (Myxozoa: Myxosporea) from the fish, Ophicephalus punctatus Bloch. Riv. Parassitol. 43(1): 147-152.

28. Chaudhary A, K Molnár, A Gupta, G Cech, HS Singh and C Székely 2017. Redescription of Henneguya chaudhuryi (Bajpai \& Haldar, 1982) (Myxosporea: Myxobolidae), infecting the gills of the freshwater fish Channa punctata (Bloch) (Perciformes: Channidae) in India. Systematic parasitology. 94(3): 403-411.

29. Raychaudhuri S and MM Chakravarty. 1970. Studies on Myxosporidia (Protozoa: Sporozoa) from the food fishes of Bengal. I. Three new species from Ophicephalus punctatus Bloch. Acta. Protozool 8: 167-173.

30. Kaur H and A Katoch 2016. Prevalence, site and tissue preference of myxozoan parasites infecting gills of cultured fish in Punjab (India). Dis. Aqua. Organ. 118(2): 129-137.

31. Deshpande M and RK Verma. 2015. Parasitic Protozoans in Some Edible Fresh Water Fishes of River Asan, District Murena. J. Adv. Lab. Res. Biol. 6(1): 12-17.

32. Thilakaratne IDSIP, G Rajapaksha, A Hewakopara, RPVJ Rajapakse and ACM Faizal. 2003. Parasitic infections in freshwater ornamental fish in Sri Lanka. Diseases of Aquatic Organ. 54(2): 157-162.

33. Mofasshalin MS, MA Bashar, MM Alam, GM Alam, D Moumita, AG Mazlan and K.D. Simon. 2012. Parasites of three Indian minor carps of Rajshahi, Bangladesh. Asian J. Animal and Veter. Adv. 7(7): 613-620.

34. Li M, J Wang, J Zhang, D Zhu, Z Gu and X Gong 2007. Observation on the Apiosoma piscicola under optical and transmission electron microscope. Acta Hydrobiol. Sinica 31(2): 211.

35. Cone DK and PH Odense 1987. Occurrence of Heteropolaria lwoffi (Fauré-Fremiet, 1943) and Apiosoma piscicola Blanchard, 1885 (Ciliata) on Salvelinus fontinalis (Mitchill) in Nova Scotia, Canada. Can. J. Zool. 65(10): 2426-2429.

36. Banerjee S and PK Bandyopadhyay. 2010. Observation on prevalence of ectoparasites in carp fingerlings in two districts of West Bengal. J. Parasitic Dis. 34(1): 44-47. 